\title{
Sosyal Devlet Olabilmenin Anahtari: Sosyal Politikalar Geliştirebilmek
}

\author{
DOI: $10.26466 /$ opus. 902955 \\ * \\ Hasan Yilmaz ${ }^{*}$ Alpcan Acar** \\ * Dr.Öğr.Üyesi, İnönü Üniversitesi, İktisadi ve İdari Bilimler Fakültesi, Malatya/Türkiye \\ E-Posta: hyilmaz@inonu.edu.tr \\ ORCID: 0000-0001-9212-8084 \\ ** Doktora Öğrencisi, İnönü Üniversitesi, İktisadi ve İdari Bilimler Fakültesi, Malatya/Türkiye \\ E-Posta: alpcan.acar@inonu.edu.tr \\ ORCID: $\underline{0000-0002-2314-6702}$
}

Öz

Sosyal devlet politikaları devlet ve birey açısından hayati öneme sahiptir. Bu kapsamda toplumun refah seviyesinin artırlması ve toplumdaki kesimler arası farklılıkların ortadan kaldırlması sosyal devlet anlayışının hedeflediği temel yaklaşımlardan olmuştur. Sosyal devlet, yaygın kabule göre, toplumda sosyal adaleti sağlamak için, devletin her türlü müdahaleleri yapması gerektiğini öne süren bir devlet anlayışı olarak; devletin elinde bulundurduğu kaynakları sosyal, politik ve ekonomik olarak adil dağıtmasını, toplumdaki tüm kesimlere ulaştırmasını ve güvenli bir hale getirmesini zorunlu kılmaktadır. Ĕ̆itim, sağlık, barınma, sosyal güvenlik ve gelirin adil dağıllımı başta olmak üzere birçok konuda bireyler arası eşitsizlikleri önlemeye yönelik ortaya çıkan sosyal politikaların, söz konusu alanlarda sorunlar gideremediği sonucuna dayanarak, etkili ol( a)madığı söylenebilir. Dolaylı ve alıntısal araştırma yöntemi esas alınarak yürütülen bu çalışmada, sosyal devletin tanımına, temel ilkelerine ve sosyal politika kavramına yer verilmiştir. Bu kavramlar üzerinden sosyal politikalar üretmenin hayati öneme sahip olduğu, sosyal devletin ancak bu şekilde gelişebileceği öne sürülmüştür. Çalışmanın sonunda ise sosyal devlet olabilmenin anahtar koşulunun; sosyal politikalar üretebilmek, uygulayabilmek ve yayabilmek olduğu sonucuna ulaşılmıştır.

Anahtar Kelimeler: Devlet, Politika, Sosyal Devlet, Sosyal Politika. 


\title{
The Key To Being A Socialstate: Developing Social Policies
}

\begin{abstract}
Social state policies are of vital importance for the state and the individual.In this context, increasing the welfare level of society and eliminating the differences between segments in society were one of the approaches aimed at the understanding of the social state. In generally, Welfare state, in order to achieve social justice in society, suggesting that the state must do with any kind of government intervention as a state in possession of the resources of social, political, and economic justice necessitates a safe place to make transport and distribute to all sectors of the community. It can be said that social policies that emerged to prevent inequalities between individuals in many areas, especially education, health, housing, social security and fair distribution of income, could not be effective based on the result that they could not solve the problems in these areas. In this study, which is carried out on the basis of indirect and citational research methods, the definition of the social state, its basic principles and the concept of social policy are included. It has been argued that it is of vital importance to produce social policies based on these concepts, and that the social state can only develop in this way. At the end of the study, the key condition of being a social state; it has been concluded that social policies can be produced, implemented and spread.
\end{abstract}

Keywords: State, Politics, Social State, Social Policy 


\section{Giriş}

İnsanlar yaşamları boyunca toplum içinde birbirinden farklı statülerde yer almaktadır. İnsanlığın tarih boyunca geçirdiği evrelere bakıldığında bu durumu görebilmek mümkündür. İnsanların yaşadığı farklılıklar onların temel haklarında eksilme veya yok olmalara neden olmamalıdır. Bu olumsuzlukları gözetip, sorunları çözebilecek mevki; bulundukları toplumun en üst iktidarı olan devlet olmalıdır. Zira devletin ortaya çıkışında toplumların bir arada yaşama arzusu olduğu aşikârdır. Devlet; vatandaşın koruyan, kollayan ve ona insan onuruna layık bir şekilde yaşama hakkı sunan bir yapıda olmalıdır. Devletler ise sosyal ve ekonomik gelişmelerden etkilenen bireylerin yaşadıklarına karşı politikalar üretebilmeli, sorunları zamanında çözebilmelidir. Nitekim dünyanın birçok ülkesinde anayasa ve kanunlarda sosyal devlet ve işleyişine ait ibareler yer almaktadır. Böylelikle devletler hukuksal statüsünü kazandırdığı sosyal devlet ilkesinin sorumluluğunu da almaktadir.

Tarihin ilk dönemlerinden günümüze kadar birçok devlet tanımı yapılmış ve bu kavramlar detaylı olarak incelenmiştir. Kimi düşünürlere göre devlet, birlikte yaşama zorunluluğundan doğmuştur, kimilerine göre doğal bir oluşumdur, kimine göre ise bir toplum sözleşmesidir. İnsanların bir arada yaşama zorunluluğundan ortaya çıktı̆̆ kabul edilen devlet kavramına ait yaklaşımlar farlılıklar göstermektedir. Devlete ait yaklaşımlarda; devletin ortaya çıkış nedeni, halkların gelenek ve göreneklerine göre ele alınmış ve dolayısıyla devletin toplumla olan ilişkisi göz ardı edilmemiştir.

Devletin vatandaşına birtakım hizmetler sunması, hayat standartlarını yükseltmek istemesi ve bu yönde çalışması, devlete ait yaklaşımları da etkilemiş ve devlete farklı görevler yüklemiştir. Her alanda vatandaşın firsat eşitliğini, gelir dağılımında adaleti, asgari yaşam standartlarını sağlaması gibi görevler devletin önemli ve öncelikli konuları haline gelmiştir. Bireyin temel haklarını savunması, özgürlüklerini koruyucu rol üstlenmesi, kamu kaynaklarını kullanılırken adalet ilkesine göre davranması ve diğer tüm hizmetlerde eşit davranması devletin sorumlulukları arasındadır. Refah devleti ve sosyal devlet anlayışının oluşmasında bu sorumlulukların daha ileri taşınması ve bireyin yaşam standartlarının yükseltilmesi ana hedef olmaktadır.

Sosyal devlet anlayışında toplumun önemli bir kesimi, devletin ekonomik ve sosyal yaşama müdahale etmesini istemiş ve bunu siyasi ve hukuki olarak 
bir vazife olarak kabul etmiştir. Devletin varlığının zorunlu olarak kabul gördüğü bu anlayışta devlet, bir jandarma görevi üstlenerek, bireylerin can ve mal güvenliğini koruyan ve özel mülkiyeti, saldırılara karşı savunan yapıdadir.

Günümüzde sosyal devlet anlayışına sahip ülkelerin varlığı gelişmişlik düzeyi ile açılanabilmektedir. Gelişmiş ülkelerde her ne kadar ideolojik aç1dan farklı bir durum söz konusu olsa da vatandaşın refahı gözetilerek yapılan hizmetler, yani sosyal devlet anlayışı görülmektedir. Bazı kaynaklarda İsveç, Norveç ve Finlandiya gibi örneklerin gösterilmesi bunu ifade etmektedir. Devletin rejimi, ideolojik yapısi, siyasal sistemi yerine ekonomisi ve vatandaşına verdiği değerle ifade edilmektedir.

Toplumsal sorunlar ve ekonomik kaygların artığı dönemlerde bireylerin devletten beklentileri de aynı oranda artış göstermektedir. Özellikle sorunlu olarak atfedilen dönemlerin aşılmasında devletin oynayacağ öncül rol son derece kıymetlidir. Toplumsal yapı da vatandaşını korumayı, kalkındırmayı ve olumsuz koşulların bertaraf edilmesini hedefleyen devletlerin uygulayacağı politikalar ana belirleyici rolü üstlenmektedir. Bu çalışmada sosyal devlet olmanın anahtar kavramı olarak görülen sosyal politikaların literatür taraması neticesinde genel bir çerçevesinin çizilmesi esas alınmıştır. Dolaylı ve alıntısal araştırma yöntemini esas alarak yürütülen bu çalışmada sosyal devlet olabilmenin ana unsuru olan sosyal politikaların nitelik ve kapsamı çizilmeye çalışılmıştır.

\section{Sosyal Devlet}

Sosyal devlet kavramının ortaya çıkışı 20.yy Batı demokrasilerine dayandırıliyor olsa da, kavramın kökenleri daha eskilere uzanmaktadır. Sosyal devlet kavramı, tedrici bir şekilde 1940'lı yılları takiben Avrupa'da önem kazanarak geçerliliğini kazanmıştır. Kavramın artan önem ve geçerliliği Dünya ekonomisinde meydana gelen dönemsel değişimler ve kırılmalardan etkilenerek sorgulanmaya başlamıştır (Türkoğlu, 2013, s.278). Kavramsal olarak ilk kez İngiliz Başpiskopos WilliemTemple tarafından 1941 yılında kullanılan sosyal devlet, ekonomide devletin rolü ve müdahalesi ile sosyal refahın oluşabileceğini işaret etmiştir. Bu bakımdan sosyal devlet aynı zamanda müdahaleci, yeniden dağıtıcl, düzenleyici ve girişimci devlettir (Aktan, 1995, s.73-74). 
M.Ö. ikinci yüzyılda Mısır medeniyetinde dul ve yetimlere yapılan yardımlar ilk sosyal yardım uygulamaları (Şenocak, 2009, s.416) olsa da kavramın sosyal devletçilik yönü bu dönemde oluşmamıştır. Diğer bir göze çarpan uygulama örneği ise Hz. Yusuf'un yedi yıl süren bolluk yılında depoladığı tahılı arkasından gelen yedi yıl kıtlık süresince Mısırlılara dağıtmasıdır (Richardson, 1970, s.4). Bu ve benzeri sosyal yardımların birleşerek güvenlik ve ekonomik gerekçeleri de içeren bir yapıya dönüşmesi ile birlikte devletler, zorunlu politikalar üretmek ve sosyal devlet anlayışını sahiplenmek zorunda kalmıştır. Uygulama örneklerinin çoğalması ve bir insan hakkı olan sosyal güvenlik ve sosyal adalet gibi fikirlerin önem kazanması sosyal devlete temel oluşturmuş̧tur.

Ayrıca İngiltere'de din görevlilerinin bazı yaklaşımlarında coğrafya, tarih ve kültürün etkileri anlaşılmaktadır. Bu açıdan bakıldığında; İngiltere'de yoksul yasaları diye bilinen (PoorLaws) kurallar öncesinde merkantilist yaklaşım ön planda olmuş ve genel olarak elit gruplar, çalışmadan yaşayan herkese "yoksul" "poor" olarak yaklaşmıştır. Bu bakımdan yoksullar halkın bizatihi kendisi olarak kabul edilmiştir (Polanyi, 1986, s.104).

Sosyal devlet anlayışı 20. yüzyılda önemini artırmıştır. Almanya kabul ettiği Weimar Anayasası ile (1919) sağlık, çalışma, aile ve eğitim haklarını güvence altına alarak bu konuda önemli bir mesafe almıştır. Diğer önemli gelişmeler; II. Dünya Savaşı sonrasında 1947 İtalya, 1949 Almanya ve 1958 Fransa'da anayasal düzenlemelerdir (Bulut, 2003, s.176-177). Böylelikle Avrupa'da sosyal devlet anlayışının hukuksal çerçevesi oluşturulmuştur. Sonraki yıllarda ise özellikle 1960'lı ve 1970'li yıllarda birçok ülkede dikkat çekici büyüme hızı görülmektedir. Belirli dönemlerde gece bekçisi, kanun ve düzen koruyucusu, militarist ve hatta totaliter yönetimin baskıcı organı sayılan devletler, artık ağırlıklı bir şekilde toplumsal refahın üretimi ve dağıtımı ile meşgul olan kurumlar haline gelmiştir (Andersen, 1990, s.1). Toplumsal refah ve sosyal adalet ilkesini edinen devletlerin özellikle küresel sosyo-ekonomik yapı içerisindeki mücadelesi bu dönemden sonra daha da zorlaşmıştır.

Geçtiğimiz yüzyılın önemli olaylarından 1929 Ekonomik Buhranı sosyal devlet için dönüm noktası olmuştur. Krizden hemen sonra Keynesyen ekonomik model önem kazanmış ve yaşanan para krizlerini aşabilmek için yöntemler aranmıştır. Bununla birlikte 1945-1975 arası dönem sosyal devlet anlayışında altın çağ olarak ifade edilir. Bu dönemde devletlerin temel öncelikleri hayat standartlarını yükseltebilmek ve sosyal politikalar geliştirebilmek 
olmuştur (Durdu, 2009, s.42). Buradan anlaşlacağı gibi kurumsal mekanizmaların ortaya çıkması ve devletlerin sosyal politikalar geliştirebilmesi sosyal devlete önem kazandırmıştır. Bir başka açıdan Keynes'in ortaya koyduğu felsefe, devletin konumunda ve işleyişinde köklü bir değişim başlatmıştır. Bu sırada devletlerin sosyal ve ekonomik hayatta elde ettiği roller ile ilgili liberal öğretilerde de değişimler yaşanmıştır (Şaylan, 2003, s.98).

Modern dönemde refah devletinin temelleri arasında İngiltere'de temel eğitimi düzenlemek için yapılan yasal düzenlemeler örnek gösterilmektedir. Modern refah devletinin başlangıcı olarak kabul edilen bir diğer yaklaşım ise, 1883 ile 1889 yılları arasında Bismarck tarafindan uygulamaya konulan sosyal sigorta uygulamasıdır. Sosyal sigorta tekniği adı verilen yöntem ile gelişen sosyalist akımlara karşı, geleneksel yöntemler ile mücadele ederken diğer taraftan sosyal politika alanında reform hareketleri başlatmak amaçlanmıştır (Özmen, 2017, s.602-603). Söz konusu teknik, literatürde refah devleti anlay1şının temel taşı olarak kabul edilmektedir.

Devletler kurulduğundan itibaren vatandaşına hizmet amacıyla çeşitli politikalar üretmek ve vatandaşını korumak istemektedir. Bu durum devletin varlık koşuludur. Sosyal politika anlayışının temelinde vatandaşı korumak ve kollamak fikri yer almaktadır. Vatandaşını her türlü zorluğa karşı koruyan devlet, sosyal devlet kavramına uygun bir devlet örneği teşkil etmektedir. Bu nedenle sosyal devletin yapısı, nitelikleri ve vatandaşına öngördükleri önem arz eden bir durum olmuştur. Böylelikle sosyal devlet, ilkesel olarak ortaya çıkan bir devlet yaklaşımı olmaktadır.

İlkesel olarak sosyal devlet anlayışı iktidarlara farklı sorumluluklar yüklemektedir. 20. Yüzyılın sonlarına doğru sosyal devlet anlayışının getirmiş olduğu sosyal refah uygulamaları yoğun eleştirilere ve tartışmalara maruz kalmıştır. Bu yoğun eleştirilerin temelini ise, sosyal refah uygulamalarının giderek artması sonucu kamu bütçesinde oluşan maliyetler ve bunun bir yük haline geldiği tartışmasıdır. Bu durum devletin kamu hizmetlerini tam anlamiyla yerine getirmesinde engel teşkil edebilmektedir (Bulut, 2003, s.173). Böylelikle devletlerin sosyal politikalar uygulaması ile aşırı büyümesi sonucu ekonomik ve siyasal sorunların beraberinde gelebileceği öngörüsü oluşmaktadır. 


\section{Sosyal Devletin Tanımı}

Sosyal devletin kuramsal temeli 1930'lu yıllar olsa da olgunlaşma dönemi İkinci Dünya Savaşı sonrası olarak bilinmektedir. Öncelikle sosyal yardım hizmetleri, daha sonra sosyal güvenlik hizmetleri bu kurumsallaşma sürecine dâhil olurken, kavramsal olarak sosyal devlet; savaş sonrasında olgunlaşma sürecine girmiştir. Sosyal devlet ilkesinin temel hatlarında devletin sahip olduğu yetkiler bulunmaktadır. Bu minvalde devlet çeşitli yollar ve enstrümanlarla toplumsal hayata ve ekonomiye müdahalede bulunma yetkisine sahiptir. Netice itibariyle sosyal devlet ilkesi üzerinden devlet, ekonomiye ve toplumsal hayata müdahalede yetkili mercii olarak belirlenmektedir. Devlet bu yetkilerini kullanırken finansman olarak vergi uygulamaların kullanabilmektedir. İkinci olarak devletin sahip olduğu yetki çok boyutlu bir yapıya sahiptir. Bu çok boyutlu yapıda devletin fiyatları denetleme, Kamu İktisadi Teşebbüsleri vasıtasıyla üretici konumunda bulunabilmesi ve fiyatların belirlenmesindeki rolleri ön plana çıkmaktadır. Bu yetkilerin altında yatan temel amaç sağllk, eğitim, istihdam ve birçok alandaki ihtiyaçların toplumun tamamına açık ve ulaşılabilir olmasının devlet kanalıyla güvence altına alınmasıdır (Güler, 2006, s.3-4). Devlet, kamusal araçlar ve devlet olmanın verdiği yetkiler ile vatandaş nezdinde bölüşümü adil yapmakla sorumlu olduğu için sosyal devlet kavramı kapsamında müdahaleci bir rol üstlenmektedir.

Sosyal Devlet veya Refah devleti; toplumda barış ve sosyal adaleti sağlamak için, devletin her türlü müdahaleleri yapması gerektiğini öne süren bir devlet anlayışıdır (Özbudun,2010, s.135). Ayrıca devletin elinde bulundurduğu kaynakları sosyal, politik ve ekonomik olarak adil dağıtması, toplumdaki tüm kesimlere ulaştırması ve güvenli bir hale getirmesi ifade edilmektedir (Bell, 2016, s.3-4). Diğer yandan, sosyal devlet, sosyal güvenlik ve sosyal adaleti tesis etmeye çalışırken, sosyal eşitsizlikler, yoksulluk ve işsizlik gibi konular ile de mücadele edendevlettir. "Sosyal Devlet" veya "Refah Devleti" dar çerçevede ele alındığında, geleneksel sosyal iyileşme alanı olarak tanımlanarak; gelir transferleri, sosyal hizmetler ve belirli ölçüde bireylerin barınma sorunlarına eğilen bir kavram olarak nitelendirilmektedir. Daha geniş çerçevede ise, genellikle politik ekonomi alanından hareketle; devletin ekonomiyi yönetme ve organize etme konusundaki büyük rolüne odaklanmaktadır. Bu doğrultuda istihdam, ücretler ve makro-mikro ekonomik konular refah devleti kompleksinin ayrılmaz bileşenleri olarak kabul edilmektedir 
(Andersen, 1990, s.1-2). Refah devleti veya sosyal devlet anlayışı ilk hukuksal adımlarını atarken, sosyal yardım programları da bu adımlara eşlik etmektedir.

İngiltere'de başlayan sonra Avrupa'ya ve dünyaya huzla yayılan sosyal programlardan birçok devlet etkilenmiştir. Özellikle iş kazası sigortası ile örneklenen yardım programları daha sonra işverenleri ve kurumları ortak etmiş ve kanuni düzenlemeler yapılmıştır (Sallan Gül, 2006, s.145). Sosyal devlet genel olarak kendi içerisinde ikili veya üçlü yapıda literatüre aktarılmaktadır. Bu alana ait bir görüş; minimal ve kurumsal olarak sosyal devleti ikiye ayırırken (Abrahamson, 1999, s.395-396), diğer bir görüş ise pozitif, sosyal güvenlik ve sosyal refah şeklinde üç gruba ayırmaktadır (Özdemir, 2007, s.129).

Sosyal refah devleti yaklaşımı, devletin sosyo-ekonomik alana müdahalesi anlayışı, bireyleri koruyucu tutumu, demokratikleşme hareketleri ile beraber sosyal-ekonomik ve özgürlüklerin anayasal güvence altına alınması, sosyal refah devletinin yaklaşık yarım asırlık bir "altın çağ" yaşamasına neden olmuştur. Bu doğrultuda eşitlikçi ve paylaşımcı değerlerle kurgulanan sosyal refah devleti, ekonomik kalkınmanin ve beraberinde toplumsal refahın tahsis edilmesinde devleti anahtar kavram olarak benimsemiştir (Acar, 2017, s.250-251). Bireyin mutlak özgürlügü̈ üzerine kurulan ve sanayi devrimi sonrası ortaya çıkan toplumsal karşıtlıklara değinmeyen klasik liberal anlayışa getirilen eleştiriler, sosyal devletin düşünsel temellerini oluşturmuş ve uygulama alanının oluşmasını sağlamıştır. Bu doğrultuda ortaya çıkan anlayış çerçevesinde devlete atfedilen rol, özgürlük konularında etkisi artırmak; yani vatandaşlara kişisel ve siyasal haklar tahsis edip kenara çekilmemekle beraber sosyal ve ekonomik hakları içeren çeşitli faaliyetlerde bulunmaktır (Bulut, 2003, s.175).

Literatürde önemli bir kesime göre; refah devleti veya sosyal devlet, tepkisel olarak ortaya çıkmıştır. Buna göre kapitalist ekonomilerin sanayileşme sonrası oluşturduğu sorunlar, artan eşitsizlikler ve sosyal güvenlik sorunları karşısında siyasal hakları öne çıkararak, devleti bu süreçte seyirci kalmaması ve müdahale etmesi fikrinden oluşmuştur. Bu açıdan bakıldığında sosyal devlet, bireylere asgari geçimi sağlamaya yönelik güvence veren, sosyal güvenliği sağlayan, toplumdaki tüm kesimlere eşit düzeyde eğitim, sağlık, barınma gibi hizmetler üretebilen devlet modelidir (Şenkal, 2005: s.275- 276). Çünkü sosyal devlet, bireylerin temel hak ve özgürlükleri başta olmak üzere, 
medeni hakları, mülkiyet hakları, siyasal hakları, anayasal katılımları gibi konularda belirli ölçüde özellikleri belirleyen (Craig, 2002, s.670) bir yapıda olmalıdır.

\section{Sosyal Devlet Anlayışının Temel İlkeleri}

Devletler karakteristik özellikleri bakımından, bulundukları dönemlerin ideolojik hareketliliğinden ve döneminin şartlarından etkilenerek değişebilmektedir. Sanayi Devrimi ve devrimin oluşturduğu etkiler sonucunda, modern devlet ortaya çıkmaya başlamıştır. Modern devletin karşılaştığı dönüm noktaları arasında Dünya Savaşları ve 1929 dünya ekonomik krizi örnek gösterilebilir. Sosyal devletin ortaya çıkış süreci ve takiben gelişimiyle yaşanan kurumsallaşma, sosyal devletin II. Dünya savaşı sonrası 1970'li yıllara kadarki süreci “Altın Çağ" olarak tasvir edilmiştir (Gümüş, 2010a, s.118). 1973 yılında yaşanan petrol krizi ve beraberindeki ekonomik dalgalanmalar yalnızca ekonomik eksenli etkilerle sınırlı kalmamıştır. Bu bağlamda yaşanan birçok gelişme ve sonuçlar devletler özelinde de yeni yaklaşımlar ve politikaların ele alınmasına yol açmıştır. Bu süreçten sosyal devlet anlayışı da derinden etkilenmiştir. Özellikle 1980'li yıllarda ABD ve İngiltere'nin öncülüğünü yaptığ 1 neo-liberal ekonomi politikaları ile piyasa ekonomisi kapsamında devletin ekonomi ve sosyal alandaki rolü farklı bir zemine taşınarak sosyal devlet ilkesi tartışılmaya başlanmıştır. Bu tartışmaların temelini attığı yaklaşımda ise, devletin ekonomik ve sosyal yönünün azaltılması temel motivasyondur (Türkoğlu, 2013, s.277).

Sosyal devlet ilkesi, ülkelerin temel anayasal ilkelerinden biri olarak kabul edilebilmektedir. Devletin nesnel olarak sahip olunan haklarından yararlanamayacak durumda olan ve güçsüz olarak nitelendirilebilen kesimleri koruma görevi olarak tanımlanmaktadır (Venckienè, 2014, s.33-34). Bu bağlamda refah devleti ile ilgili tartışmaların ortak iki noktası vardır. İlk olarak, sosyal yurttaşlı̆̆ın genişlemesi ile sınıfın belirginliğinde bir azalma söz konusu olacak mı? Yani refah devleti kapitalist toplumu temelden dönüştürebilir mi? İkinci olarak ise, refah devletinin gelişimini tetikleyen nedensel güçler nelerdir? (Andersen, 1990, s.9). Söz konusu tartışmalar sonrası oluşan kanaatler esasen sosyal devletin temel ilkelerini ortaya koymaktadır.

Sosyal devlet ilkesinin dört temel özelliği bulunmaktadır. Bu dört temel özellik şu şekilde sıralanabilir (Gümüş, 2010b, s.188): 
- "Insan onuruna yaraşır hayat standardının sağlanması",

- "Sosyal adaletin sağlanması",

- "Devletin piyasaya müdahalesi ve adil gelir dağılımmnn sağlanması",

- "Sosyal ve ekonomik hakların sağlanmasıdır".

Kapitalizmin sistemsel olarak ortaya çıkardığı güç-refah dağılımındaki eşitsizlikler sistemin sorgulanmasına ve daha güçlü bir muhalefetle karşılaşılmasına yol açmıştır. Kapitalizmin beraberinde getirdiği sorunlar ve bu sorunların derinleşmesi, artması ve tepki çekecek boyutlara ulaşması sosyal güvence ve insana yatırım gibi uygulamaları zorunlu hale getirmiştir. Tüm bunlar ele alınarak bakıldığında kapitalizm, kendi geleceği için birtakım temel ilkelerini de göz ardı ederek içerisinde devlet müdahalelerini barındıran sosyal devleti, kendisi muhatap etmek zorunda kalmıştır (Ertürk, 2016, s.155). Sosyal devletin ana hatlarında, vatandaşların kanunlar karşısında sahip oldukları eşit hakları güvence altına almak, bu hak ve özgürlüklerin sosyalekonomik eşitsizlikler nedeniyle uygulanmasını önündeki engellerin kald1rılması yatmaktadır. Böylece devlet, vatandaşlarının temel bireysel hak ve özgürlüklerini daha işlevsel bir yapıya kavuşturabilmektedir. Sosyal devlet, üretim kapasitesini artırarak (ekonomik büyüme sağlanarak) toplumsal refahın da aynı paralelde artacağını öngörmektedir. Bu çerçevede devletin ekonomiye müdahalesi ekonomik büyüme, kalkınma ve toplumsal refahın artırılması için gerekli görülmüştür. Sosyal devletin ekonomideki ve beraberinde ortaya çıkan sosyal yapıdaki temel müdahalelerinin altında yatan etmenler arasında işsizliğin önüne geçilerek tam istihdamın sağlanması, sosyal dengenin korunması, gelecek güvencesinin oluşturulması, yardıma muhtaç olarak nitelendirilen bireylerin temel ihtiyaçlarının karşılanabilmesi, çalışan bireylerin durumunun iyileştirilmesi gibi etmenler bulunmaktadır. Tüm bu yaklaşımların uygulanması ve ele alınması ülkeden ülkeye değişiklikler gösterebilmektedir (Yay, 2014, s.149-150).

Sosyal devlet olmanın kriterleri ve temel argümanları ise şu şekilde sınıflandırılabilir (Ören, 2011, s.10-11):

- Sosyal devlet, hukuk devleti kavramı ile iç içe geçmiş ve hatta daha ileri bir evresi olarak vatandaşlarının sosyal ve ekonomik alanlarda temel yaşam standardının "onurlu" bir seviyeye çıkarılmasını esas almaktadır. Böylece sosyal devlet toplum içerisinde zayıf olarak kabul edilen kesimlerin toplum içerisinde ötekileştirilmesini ve ezilmelerini engeller. 
- Sosyal devlet, emek kesimlerinin toplum içerisinde uygun bir yaşamsal koşula sahip olabilmeleri için adil düzeylerde ücret almaları ve bu standardın oluşturulması ile sorumludur. Bu doğrultuda sosyal devlet işsizliğin giderilmesi sürecinden istihdam üzerine kurgulanan eğitimlerin verilmesine kadar sorumlu görülmektedir. Bu kapsamda belirli şartlar neticesinde ilgili kesimlere işsizlik yardımı veya işsizlik sigortası gibi destekler sağlanması gerekir.

- Sosyal devletin temel değerleri arasında bireylerin çeşitli haklarını güvence altına almak bulunmaktadır. Bu kapsamda sosyal devlet tüm kesimlerin bireysel özgürlüklerinden din ve vicdan özgürlüğüne kadar temel haklarını koruyucu rolüne sahiptir.

- Sosyal devlet hayatın dinamik yapısının oluşmasından çalışan nüfusun niteliğine kadar ilgilenmekle sorumludur. Bu bağlamda sosyal devlet kadın ve çocukların çalışma koşulları üzerinde temel düzenleyici role sahip olarak, bünyeleriyle orantısız işlerde çalıştırılmasının önüne geçmekle sorumludur. Bununla beraber sosyal devlet çalışanların ölüm, emeklilik ve benzeri durumlarıyla da ilgilenmektedir.

- Sosyal devlet özellikle sosyal yaşam, eğitim, ekonomik ve istihdam gibi konularda dezavantajlı kesimlerin yanında yer alarak ilgili kişilerin topluma kazandırılmasında öncül role sahiptir.

- Sosyal devlet toplum ve birey üzerindeki ekonomiden sosyal hayata kadar olan tüm süreçler üzerindeki düzenleyici ve yapıcı rolünü en etkili bir şekilde kullanabilmesi için "müdahaleci" bir politika izler.

Sosyal devlet olma ölçütlerinin, devletlerin görev ve sorumluluklarını artırdığını belirtmek mümkündür. Bu kapsamda devletlerin toplum hayatında daha belirgin hale gelmesi ve aktif bir role bürünmesi kaçınılmaz bir gerçektir. Sosyal devlet yaşadığı dönüşümler ve gelişmelerle Montesquieu'nün "Kanunların Ruhu" adlı kitabında "Jandarma Devlet" olarak tasvir ettiği ve devletin sadece güvenlik, savunma, adalet, eğitim ve diplomasi görevlerini yerine getiren (Montesquieu, 2015) ve piyasaya herhangi bir müdahalede bulunmayan klasik liberalizmin devlet anlayışından ayrılmaktadır. Bu kapsamda devlete atfedilen anlayış genişleyerek sosyo-ekonomik olaylar üzerinde de devlet, müdahaleci bir konumda ele alınmıştır (Ergenç, 2009: s.36). 
Sosyal devlet ilkesinin kullandığı araçlardan biri kuşkusuz demokrasidir. Toplumsal eşitsizliklerin ve adaletsizliklerin giderilmesinde demokrasinin işlevselliği önemli bir yere sahiptir. Demokrasinin temel taşları arasında bulunan siyasal eşitlik yaklaşımı, "sosyal eşitlik" beklentisini harekete geçirerek, devleti bu kapsamda daha faal bir rol üstlenmeye sevk eder. Demokratiklik ve ekonomik açıdan gelişmekte olan ülkelerde, tek başına gerçekleştirilen sosyal gelişmeler veya demokratik gelişmeler devletin sosyal devlet olarak kabul edilebilmesi için yeterli değildir. Sosyal devlet, yapısı bakımından uzun vadeli ve belirli amaçlara hizmet edecek politikalar üretilmesini içermektedir. Özellikle gelişmekte olan ülkelerde görülen "popülist" politikalar kısa vadeli, o günkü koşullara göre şekillenen ve mevcut dengenin bozulmamasına hizmet ettiği için bu politikaların sosyal devlet olarak adlandırılması mümkün görünmemektedir. Sosyal devlet olmak için ihtiyaç duyulan planlı ve uzun vadeli politikalar yerine kısa vadeli popülist politikalar geliştiren ülkeleri "vaatler devleti" olarak nitelendirmek yanlış olmayacaktır. Sağlam temellere oturtulmadan ve geçici bir zeminde kurgulanan politikalara sahip "vaatler devleti" tanımına uygun ülkeler, küreselleşme sürecinde neo-liberal politikalara daha fazla maruz kalarak günümüzde bu kısa vadeli yaklaşımlarından da vazgeçmiş bir görüntü çizmektedirler (Koray, 2012, s.77-78).

\section{Sosyal Politika}

19. yüzyılda yaşanan ekonomik ve sosyal gelişmelerin bir ürünü olan sosyal politika kavramının literatüre girmesi görece daha yeni sayılmaktadır (Özdemir, 2007, s.13). Genel bir sosyal politika tanımı yapmak gerekirse; devletin vatandaşlarının refah, huzur ve mutluluğunun sağlanması bakımından birçok alanla ilinti kararlar ve uygulamalar bütünü olarak ifade edilebilir. Bu çerçevede sosyal politika eğitim, istihdam, sosyal yapı ve benzeri birçok alan üzerine oluşturulabilmektedir (Bedir, 2015, s.3). Toplumun refah seviyesini artırabilmek için sosyal planlamalar ve devletin her türlü müdahalesi sonucu ortaya çıan politikalar (Cahnman, 1958, s.330) olarak da tanımlanabilir. Sosyal politika kavramı; toplumda adaleti sağlamak için sınıflar arası farklılıkları ortadan kaldırabilmek adına ortaya konan çalışmalar ve hizmetler şeklinde de ifade edilebilir.

Sanayi devrimi ve sonrasındaki süreçte toplumsal yapıda değişiklikler meydana gelmiştir. Bu bağlamda özellikle işçi sınıfının mevcut durumu ve 
toplumsal ayrışmadaki artı̧, devletlerin bu problemli alana müdahalesini kaçınılmaz hale getirmiştir. Ortaya çıkan toplumsal çatışmalar ve işçi sınıfının mevcut yapıda karşılaştıkları zorluklar gönüllü sigorta uygulamalarını doğurmuştur. Bu uygulamalar zamanla kalıcı hale gelmiş ve sosyal sigorta kavramı ortaya çıkmıştır. Böylece devletlere ilişkin sosyal politikalar ön planda yerini almıştır (Koray, 2012, s.27-28). Bunun yanı sıra emeklilik, sakatlık, işsizlik ve hastalık gibi faktörler sosyal sigortalar anlayışının gelişmesine ve hatta zorunlu olmasina neden olmuştur (Rosanvallon, 2000, s.11).

Başarılı sosyal politika uygulamalarından bahsedilebilmesi için bazı zeminlerin oluşması gerekmektedir. Devletlerin başarılı sosyal politikalar üretebilme ve uygulayabilme düzeyleri, mevcut rejimleri ile yakından ilintilidir. Devletlerin mevcut rejimlerin sosyal politikalara tanıyacakları hareket alanı başarılı bir sosyal politika için son derece önemlidir. Bu çerçevede demokratik teamüllerin baskın olduğu ülkelerde, sosyal politikalar daha geniş bir hareket alanına sahip olurken, demokratik kaidelerin yerleşmediği ülkelerde sosyal politika ve sosyal adaletin işlevsellik kazanması mümkün görünmemektedir. Sosyal politikaların kâr amacı üzerine kurgulanmaması ve kamu yararını hedeflemesi temel değerleri arasındadır (Ören, 2011, s.31-32).

Sosyal politikalar sanayileşmenin etkisiyle sistemin daha insani nitelik kazanmasını sağlamaya yönelik denge anlayışı olarak belirginlik göstermektedir. Sosyal politikanın varlığı kimilerince sistemin devamlılığı için çalışan bir mekanizma olmakla büyük bir kesim tarafından da kapitalizmin vicdanı olarak ele alınmıştır. Keynesyen iktisat anlayışının kamusal müdahalelere olanak tanıması neticesinde devletin sosyal niteliği gelişme imkânı bularak refah devletine giden yolu oluşturmuştur (Özaydın, 2008, s.164).

Sosyal politikaların kapsamını ve özelliklerini belirleyen bazı önemli etkenler bulunmaktadır. Bunlar arasında devletin ekonomik yapısı, siyasal yönetim anlayışı, sosyal politika uygulayıcısı kurumların özellikleri ve ilgili toplumun sosyal ve kültürel faktörleri yer almaktadır (Aysan, 2020, s.10). Söz konusu temel etkenler sosyal politikanın şeklini ve içeriğini belirler. Ĕgitimden sağlığa, sosyal hizmetlerden barınmaya ve sosyal güvencelere kadar tüm konuların içeriği oluşmaktadır. Diğer yandan sosyal politikaların hedefleri ise şöyle sıralanmaktadır (Ergenç, 2009, s.38):

- Sosyal politikalar, "ihtiyaç sahibi" tanımlanmasına sahip bireylerin sosyal ve ekonomik yapılarında sosyal sigorta, sosyal yardım ve sosyal hizmetler gibi uygulamalarla iyileştirmeler yapmayı hedeflemektedir. Bu 
çerçevede ihtiyaç sahibi olarak görülen bireylerin sosyal ve ekonomik olarak desteklenmesi ön plana çıkmaktadır.

- Sosyal politikalar neticesinde toplumsal düzenin ve adaletin sağlanması öncelikli hedefler arasındadır.

- Devletin sosyal politikalar vasitasıyla toplumun tüm kesimlerine ulaşabilmesi ve toplumun tüm kesimlerinin her türlü riskten korunması için sosyal güvenlik kapsamına dahil edilmesi,

- Sosyal politikalar neticesinde makro ve mikro boyutta verim elde edilmesi ve fırsat eşitliğinin de ön plana çıkarılması hedeflenmektedir. Bununla beraber toplumsal bütünleşmenin sağlanması ve tam istihdam öncelikler arasında yer almaktadır.

- Sosyal politikalar neticesinde toplumun mevcut yapiya ve sisteme olan inancının sağlanması ve korunması temel hedefler arasında bulunmaktadir.

- Sosyal dayanışma kültürünün oluşması ve toplumun her kesimine sivil örgütlere katılım olanaklarının tanınmasıdır.

Sosyal hakların yurttaşlık kavramıyla olan ilişkisi uzun temellere dayanmaktadır. Sosyal haklar çerçevesinde sorunlu alanlar olarak görülen sosyal eşitlik ve sosyal adalet konularına yeni bir bakış açısı getirilmiştir. Bu doğrultuda sosyal haklar serbest piyasa ekonomisine müdahaleyi öngörmekle beraber, vatandaşı piyasa ekonomisine indirgemeyerek piyasanın vatandaş üzerindeki ezici ve yıkıcı etkilerinden arınılmasını da içermektedir. Hak temelli düzenlemeleri temel alan sosyal politikalar, toplumu bir bütün olarak ele almaktadır (Metin, 2011, s.181-182). Halkı bir bütün olarak ele alan bu kavram, beraberinde toplumsal tabakada bir bütünleşmeyi ve aidiyet duygusunun artmasına da olanak sağlamaktadır.

Sosyal politika kavramı daha çok sosyal güvenlik, sosyal sigortacılık, sosyal yardımlar ve sosyal hizmetler uygulamaları kapsamında ele alınmaktadır. Fakat sosyal politika belirli kurumsal ilkeler çerçevesinde ortaya çıkmış ve daha sonra da kurumsallaşmıştır. Bu kurumsallaşma süreci, batılı ülkelerde meydana gelen siyasi, sosyal ve ekonomik gelişmelerden oluşmaktadır. Bu bağlamda merhamet duygusu üzerinden şekillenen ve isteğe bağlı olarak toplumsal yardımlaşma yerini, eşit haklar çerçevesinde bireylerin toplumsal risklere karşı korunduğu ve bu korunmanın kurumsal yollardan gerçekleştirildiği sosyal politikaya bırakmıştır (Sunal, 2011, s.284). 
Sosyal politikanın kabul gördüğü tanımı ve uygulama alanı, ülkeden ülkeye çeşitli farklılıklar gösterebilmektedir. Ancak kavram üzerinde büyük çoğunluğun uzlaştığı nokta sosyal politikanın başlangıcının sanayileşme, kapsamının ise sanayileşme sonucu işçi sınıfının yaşadığı sorunlara müdahale stratejisinin olduğudur. Sanayileşme başlı başına dünya üzerinde yoğun etkilere neden olmuştur. Özellikle siyasi, sosyal ve ekonomik anlamda önemli bir geçiş dönemi olarak tasvir edilmektedir. Bununla beraber sanayileşmenin karşılık bulamadığı daha doğrusu yoğun dönüşümün sefalete zemin hazırlaması dikkat çeken bir diğer husus olmuştur. Bu minvalde sanayileşmenin toplumsal zeminde daha olumlu bir iz birakması adına sosyal politikalar bir nevi denge aracı olarak görülmeye başlanmıştır (Yıldırım, 2018, s.32).

Sosyal politika, genel hatlarıyla devlet tarafindan uygulanan ve idare edilen bir yapıdır. Fakat devlet dışında toplum tarafından oluşturulan vakıf, sendika, kooperatif gibi sivil örgütlerin tedbir ve politika geliştirmesi mümkündür. Oluşturulabilecek bu tedbirlerin çerçevesini ise yasal düzenlemeler çizmektedir. Sosyal politika kapsamına giren konularda alınacak herhangi bir tedbir veya uygulamanun sosyal politika olarak nitelendirilebilmesi için düzenli, sürekli, planlı ve hukuki kurallar nezdinde gerçekleştiriliyor olması gerekmektedir (Bedir, 2015, s.10). Sosyal devlet ilkesi üzerine inşa edilen devlet politikaları, "uzlaşma arac1" olarak da devletin elini güçlendiren bir niteliğe sahiptir. Bu politikaların içerdiği eşitlik ve adaletin sağlanması kavramları, toplumsal bütünleşmeyi teşvik edici olmakla beraber vatandaşın mevcut sisteme olan inancın da artırmaktadır (Koray, 2012, s.79).

Sosyal politikalar özellikle gelişmekte olan ülkelerde geçici uygulamalar olarak ele alınmaktadır. Bu doğrultuda ele alınan politikalar devletin vatandaşlarına yaptığı bir yatırım olarak görülmekten ziyade devlet gideri olarak görülmektedir. Sosyal politikanın bu çerçevede uygulanması, toplumun belirli kesimleri arasındaki yapısal uyumsuzluğu gidermek için tasarlanan bir dizi sınırlı tedbir olarak değerlendirilmesine neden olmaktadır. Bu bağlamda ele alınan sosyal politikalar önemli ölçüde ihmal edildiğinde, devletin desteğine ihtiyaç duyan ve bekleyen kesimlerin sosyal sorunlar altında ezilmelerine yol açmaktadır (Yolcuoğlu, 2012, s.156). 


\section{Tartışma ve Sonuç}

Sosyal devlet veya refah devleti anlayışı, toplumda refah seviyesinin arttığı ve sınıfsal farklılıkların yaşanmadığı durumlarda söz konusu olabilmektedir. Liberal öğretinin tersine devlet koruyucu, kollayıcı, düzenleyici ve denetleyici bir anlayış ile hizmet etmektedir. Kapitalizmin dünyaya armağan ettiği ve neredeyse her şeyi küreselleştirdiği sosyal ve ekonomik yapıda sosyal adaletin nasıl sağlanacağı ve ne kadar sürdürülebilir olacağı merak konusudur. Bu bağlamda kimi otoriteler, sosyal adaletin tesis edilememesini sosyal politikaların başarısızlığı olarak değerlendirmektedir. Dünyada sosyal politikaların bu denli etkisiz olması küresel sermaye odaklarının iştahını daha çok kabartmaktadır. Küresel sermaye gruplarına karşı çaresiz kalan kimi devletler sosyal politikaları sadece sözde veya kâğıt üzerinde savunabilmektedir.

Toplumsal yapıda yaşanan hızlı dönüşümler, kapitalizmin yayılması ile birleşince sosyal politikalara ihtiyaç artmıştır. Devletler niceliksel anlamda yaşanan bu değişimlere, gelirin adil dağıtılmamasından dolayı toplumda oluşan sınıflar arası çatışmalara çözüm bulamamış veya yetersiz kalmıştır. Devletin bu sorunlara çözümü yine sosyal politikalar ile olacaktır ve bu nedenle sosyal politika kavramı önemini her dönem korumaktadır. Devletlerin esas görevleri arasında ideal bir sosyal adaleti tesis etmek olduğu düşünülürse bu durumda sosyal politikaların popülist olmak yerine topluma fayda sağlayan bir yapıda olması beklenir. Ancak bu şekilde devletler sosyal adaleti tesis ederek toplumdaki eşitsizlikleri en aza indirmeyi, mümkünse ortadan kaldırmayı başarır ve sosyal devletin bir gereği olan sosyal politika üretmede amacına ulaşabilir.

Unutmamak gerekir ki, tarih boyunca devletin egemenliği, varlık nedenleri gibi konuların yanında devletin görevi ve kapsamı da sık sık tartışılmaktadır. Devlete yüklenen görevler, ondan beklenenler zaman ve mekân kavramlarına göre değişmiş olsa da esasen toplumun en üst otoriteden beklentisi benzerlik gösterir. Devletin toplum üzerindeki etkisi ve rolü bu anlamda oldukça önemlidir. Farklı ideolojik görüşlerin de etkisiyle devletin yapısı da değişime uğramıştır. Devletin nasıl konumlanacağı, sosyal, ekonomik ve siyasal yapısını nasıl belirleyeceği tarihsel süreçte tartışlmıştır. Ancak şu bir gerçektir ki, devlet, vatandaşın ihtiyaçlarını karşılayabilen bir konumda olmalıdır. Dünya üzerinde genel olarak, gelir adaletsizliğinin artması, toplum- 
daki sınıfsal farklılıklar ve bireylerin ekonomik sorunları mevcut sosyal politikaların yetersiz olduğuna işaret etmektedir. Bu nedenle sosyal devlet anlayışında anahtar kavram, sosyal politikalar geliştirebilmek ve bu süreci güncel tutabilmektir. Devletlerin yapmış olduğu bazı ayni ve nakdi yardımdan daha öte kalıcı ve sürdürülebilir politikalar üretebilmek adına toplumun her kademesindeki kesimlerle sorunlar güncel olarak istişare edilmeli, kalıcı çözümler bulunmalıdır. Devlet sosyal yardımda bulunurken mevcut sorunun kalıcı çözümüne odaklanarak sürdürülebilir sosyal politikalar üretebilmelidir. 


\title{
EXTENDED ABSTRACT The Key To Being A Socialstate: Developing Social Policies \\ *
}

\author{
Hasan Yilmaz - Alpcan Acar \\ İnönü Üniversitesi
}

The state's provision of certain services to its citizens, its desire to raise its living standards and its work in this direction also affected the state's approaches and imposed different duties on the state. Duties such as ensuring the citizens' equality of opportunity in every field, justice in income distribution, and minimum living standards have become important and prioritized issues of the state. It is among the responsibilities of the state to defend the fundamental rights of the individual, to take a role to protect their freedom, to act by the principle of justice when using public resources, and to act equally in all other services. In the formation of the welfare state and social state understanding, it is the main goal to carry these responsibilities further and to increase the living standards of the individual.

Since their establishment, states have wanted to produce various policies and protect their citizens to serve their citizens. This is the existing condition of the state. The idea of protecting and watching over the citizen lies at the heart of the social policy approach. The state, which protects its citizens against all kinds of difficulties, constitutes an example of a state by the concept of a social state. For this reason, the structure of the social state, its qualities and what it predicts for its citizen has become a matter of importance. Thus, the social state is a state approach that emerges on principle.

Social state understanding has increased its importance in the 20th century. The Weimar Constitution (1919), which Germany adopted, secured the rights to health, work, family and education, and made significant progress in this regard. Other important developments; II. After World War, 1947 Italy, 1949 Germany and 1958 are constitutional regulations in France (Bulut, 2003, p.176-177). Thus, the legal framework of the social state understanding in Europe has been established. In the following years, a remarkable growth rate is observed in many countries, especially in 
the 1960s and 1970s. States, which were regarded as night watchmen, protectors of law and order, militarist and even the repressive organ of totalitarian rule, have now become institutions that are heavily engaged in the production and distribution of social welfare (Andersen, 1990, p. 1). The struggle of the states, which have adopted the principle of social welfare and social justice, especially within the global socio-economic structure, has become more difficult after this period.

The social welfare state approach, the understanding of the intervention of the state in the socio-economic sphere, the protective attitude of the individuals, the democratization movements and the constitutional guarantee of social-economic and freedoms have caused the social welfare state to experience a "golden age" for about half a century. In this direction, the social welfare state, built with egalitarian and sharing values, has adopted the state as the key concept in the allocation of economic development and social welfare (Acar, 2017, p. 250-251). The criticism of the classical liberal understanding, which is based on the absolute freedom of the individual and does not refer to the social antagonisms that emerged after the industrial revolution, formed the intellectual foundations of the social state and provided the application area. The role attributed to the state within the framework of the understanding that emerged in this direction is to increase its influence on freedom issues; that is, to allocate personal and political rights to citizens and not stand aside, but to engage in various activities involving social and economic rights (Bulut, 2003, p.175).

The introduction of the concept of social policy, which is a product of the economic and social developments experienced in the 19th century, into the literature is considered relatively new (Özdemir, 2007, p. 13). If it is necessary to make a general definition of social policy; It can be expressed as a set of decisions and practices about many areas in terms of ensuring the welfare, peace and happiness of the citizens of the state. In this framework, social policy can be formed on education, employment, social structure and many similar areas (Bedir, 2015, p.3). It can also be defined as social planning and policies that emerge as a result of any intervention of the state to increase the welfare level of the society (Cahnman, 1958, p. 330). The concept of social politics; can also be expressed in the form of 
works and services put forward to eliminate the differences between classes to ensure justice in society.

It should not be forgotten that in addition to issues such as the sovereignty of the state and the reasons for its existence, the duty and scope of the state are frequently discussed throughout history. Although the duties assigned to the state and what is expected of it differ according to the concepts of time and space society's expectations from the highest authority are similar. The influence and role of the state on society are very important in this sense. The structure of the state has also changed under the influence of different ideological views. How the state will be positioned and how it will determine its social, economic and political structure has been discussed in the historical process. However, it is a fact that the state must be in a position to meet the needs of the citizen. In general, the increase in income inequality, class differences in social and economic problems of individuals all over the world point out that the current social policies are insufficient. Therefore, the key concept in social state understanding is to develop social policies and to keep this process up-to-date. To produce permanent and sustainable policies beyond some in-kind and monetary aid provided by the states, the problems should be consulted with all segments of the society and permanent solutions should be found. While providing social assistance, the state should be able to produce sustainable social policies by focusing on the permanent solution to the present problem.

\section{Kaynakça / References}

Abrahamson, P. (1999). The Welfare modelling business. Social Policy \& Administration, 33(4), 394-415.

Acar, E. (2017). Neoliberalizm ve sosyal refah devleti ekseninde üçüncü yol yaklaşımı. Kastamonu Üniversitesi İktisadi Ve İdari Bilimler Fakültesi Dergisi, 18(1), 248-263.

Aktan, C. C. (1995). 21.yüzyll için yeni bir devlet modeline doğru optimal devlet, kamu ekonomisinin ve yönetiminin yeniden yapılanması ve küçültülmesine yönelik öneriler, İstanbul: TÜSİAD Yayınları.

Andersen, G. E. (1990). The three worlds of welfare capitalism. Polity Press.

Aysan, M.F. (2020). Geleceğin Türkiye'sinde sosyal politikalar. İstanbul: İlke Yayınları. 
Bedir, E. (2015). Sosyal politikaya ilişkin genel bilgiler ve sosyal politikanın araçları (4. Baskı.). A. İ. Oral,\& Y. Şişman (Ed.), Sosyal Politika içinde. Eskişehir: Anadolu Üniversitesi Yayın.

Bell, L. A. (2016). Theoretical foundations for social justice education. (Edt: M. Adams, L.A. Bellwith D.J. Goodman, K.Y. Yoshi) Teaching For Diversity And Social Justice, 3. Edition. Routledge: New York.

Bulut, N. (2003). Küreselleşme: sosyal devletin sonu mu?.Ankara Üniversitesi Hukuk Fakültesi Dergisi, 52(2), 173-197.

Cahnman, W.J. (1958). Man and economy: essays and discussion of the economic theory and policy. The American Journall of Sociology, 64(3), 320-331.

Craig, G. (2002). Poverty, social work and social justice. British Journal Of Social Work,32, 669-682.

Durdu, Z. (2009). Modern devletin dönüşümünde bir ara dönem: sosyal refah devleti. Muğla Üniversitesi Sosyal Bilimler Enstitüsü Dergisi, 22, 37-50.

Ergenç, S. (2009). Sosyal politikalarda ve sosyal hizmetlerde değişim süreci (yeni bir model önerisi). Denetişim, (1), 35-41.

Ertürk, A. S. (2016). Küreselleşen dünyada küreselleşemeyen sosyal adalet. Ankara: Alter Yayınclik.

Güler, B. A. (2006). Sosyal devlet ve yerelleşme. Memleket Siyaset Yönetim-Dört Aylk Kurumsal Dergi.

Gümüş, A. T. (2010a). Sosyal devlet anlayışınn gelişimi ve dönüşümü. Selçuk Üniversitesi Hukuk Fakültesi Dergisi, 18(2), 117-158.

Gümüş, A. T. (2010b). Sosyal devlet anlayışınn gelişimi ve dönüşümmü. İstanbul: On İki Levha Yayınclik.

Koray, M. (2012). Sosyal politika (4. Baskı.). Ankara: İmge Kitabevi.

Metin, O. (2011). Sosyal politika açısından Akp dönemi: sosyal yardım alanında yaşananlar. Çalışma Ve Toplum Dergisi, 28, 179-200.

Montesquieu, B. (2015). Kanunlarm ruhu üzerine. (Fehmi Baldaş,Çev.). İstanbul: Hiperlink Yayınları.

Ören, K. (2011). Sosyal politika. Ankara: Pelikan Yayıncllk.

Özaydın, M. M. (2008). Küresel etkilerle şekillenen sosyal politika anlayışı ekseninde sosyal politikaların geleceğini tartşmak. Gazi Üniversitesi İktisadi Ve İdari Bilimler Fakültesi Dergisi, 10(1), 163-180.

Özbudun, E. (2010). Türk anayasa hukuku, Ankara: Yetkin Yayınları.

Özdemir, S. (2007). Küreselleşme sürecinde refah devleti (2. Bask1). İstanbul: İstanbul Ticaret Odasi. 
Özmen, Z. (2017). Avrupa'da sosyal güvenlik sisteminin finansmanı: farklı refah devletleri üzerine bir inceleme. Karabük Üniversitesi Sosyal Bilimler Enstitüsü Dergisi, 7(2), 600-620.

Polanyi, K. (1986). Büyük dönüşüm: çağımızm siyasal ve ekonomik kökenleri. (Ayşe Buğra,Çev.). İstanbul: Alan Yayıncllı.

Rosanvallon, P. (2000). The new social question: rethinking the welfare state. New Jersey: Princeton University Press.

Richardson, J. H. (1970). İktisadi ve mali yönüyle sosyal güzenlik, (Turan Yazgan,Çev.), İstanbul: ÏÜ. İktisat Fakültesi Yayınları.

Sallan Gül, S. (2006). Sosyal devlet bitti, yaşasm piyasa! yeni liberalizm ve muhafazakârllk kıskacinda refah devleti. Ankara: Ebabil Yayınları.

Sunal, O. (2011). Sosyal politika: sosyal adalet açısından kuramsal bir değerlendirme. Ankara Üniversitesi Sbf Dergisi, 66(3), 283-305.

Şaylan, Gencay. (2003). Değişim, küreselleşme ve devletin yeni işlevi, Ankara: İmge Kitabevi.

Şenkal, Abdülkadir. (2005). Küreselleşme çağında sosyal politika, İstanbul: Alfa Yayınları. Şenocak, H. (2009). Sosyal güvenlik sistemini oluşturan bileşenlerin tarihi süreç ışı̆̆ında değerlendirilmesi. Sosyal Siyaset Konferansları Dergisi, 56.

Türkoğlu, İ. (2013). Sosyal devlet bağlamında Türkiye'de sosyal yardım ve sosyal güvenlik. Akademik Incelemeler Dergisi, 8(3), 275-305.

Venckienė, E. (2014). Some aspects of the I,mage of social state under the rule of law in the interwar period in Lithuania. International Journal of Arts and Commerce, $3(2), 33-42$.

Yay, S. (2014). Tarihsel süreçte Türkiye'de sosyal devlet. 21. YüzyıldaEğitim ve Toplum, 3(9), 147-161.

Yıldırım, B. (2018). Endüstrileşme ve sosyal politika arasındaki ilişki üzerine bir değerlendirme. Ufkun Ötesi Bilim Dergisi, 18(1), 30-44.

Yolcuoğlu, İ. G. (2012). Türkiye'de sosyal politika ve sosyal hizmetlerin geliştirilmesi. Toplum Ve Sosyal Hizmet, 23(2), 145-158.

\section{Kaynakça Bilgisi / Citation Information}

Yilmaz, H. ve Acar, A. (2021). Sosyal devlet olabilmenin anahtarı: sosyal politikalar geliştirebilmek. OPUS-Uluslararası Toplum Araştırmalarn Dergisi, 17(37), 4738-4759. DOI: 10.26466/opus.902955 